\title{
Growth performance of brown-golden marine microalga, Isochrysis sp., cultivated in alternative algal culture media
}

\author{
Nai-Han Tan ${ }^{1}{ }^{*}$, Kit-Shing Liew ${ }^{1}$, Cheng-Kai Shi², Sitti Raehanah Muhamad Shaleh${ }^{1}$, and Leong-Seng Lim ${ }^{1}$ \\ ${ }^{1}$ Borneo Marine Research Institute, Universiti Malaysia Sabah, Jalan UMS, 88400 Kota Kinabalu, Sabah, Malaysia \\ 2 Yuan Long Pearl Co., Ltd., No. 285 Yunnan Road, Beihai, Guangxi Zhuang Autonomous Region, China
}

${ }^{*}$ Corresponding author: ptnh_mmap4@yahoo.com

\begin{abstract}
The present study aimed to evaluate the suitability of introduced algal culture media as an alternative to the general enriched seawater media in the laboratory cultivation of Isochrysis sp., a marine microalga commonly cultivated for aquaculture purposes. Isochrysis sp. was established into culture in three replications using three experimental algal culture media (Walne's medium as a control, China-contributed culture medium (CCM) and CCM supplemented with vitamins (CCM + Vit)). The experiment was performed with a continuous illumination for a period of seven days at $25 \pm 1^{\circ} \mathrm{C}$. The effect of introduced algal culture media (CCM and CCM + Vit) on the growth performance of Isochrysis sp. was highlighted. CCM demonstrated promising results for the cultivation of Isochrysis sp. A maximum cell density of $9.16 \times 10^{6} \pm 5.40 \times 10^{5} \mathrm{cells} \mathrm{mL}^{-1}$, which corresponded to an instantaneous growth rate $(r)$ of 0.21 cell day $^{-1}$ and a doubling time $\left(T_{2}\right)$ of 3.29 days, was observed in Isochrysis sp. cultivated in CCM. In view of its potential and reduced preparation labour, CCM may be recommended as an alternative to the general enriched seawater media in the cultivation of Isochrysis sp. in laboratories with basic facility as well as small- and medium-scale aquaculture hatcheries.
\end{abstract}

Keywords: Isochrysis sp., Marine microalga, Algal growth, Alternative culture media, Cell density.

\section{Introduction}

Aquaculture is the farming of fish, shellfish and aquatic plants under controlled freshwater and seawater conditions (Food and Agriculture Organisation of the United Nations, 1988). It implies some form of intervention in the cultivation process to enhance production to meet the increasing demand for high quality protein, as well as to ensure that the existing fisheries remain sustainable through replenishment of dwindling wild stocks due to overfishing (Adewumi and Olaleye, 2011; Parker, 2011). In aquaculture practice, microalgae from the genera Chaetoceros, Dunaliella, Isochrysis, Nanochloropsis, Pavlova and Tetraselmis are commonly cultivated as essential live feed for all life stages of bivalves, the early larval stages of crustaceans, zooplankton (for example, rotifers and copepods) and to a lesser extent, marine finfish larvae (Meireles et al., 2003; Creswell, 2010; Thu et al., 2015); as well as for improvement of water quality in marine finfish and shellfish hatcheries (Khatoon et al., 2007; Priyadarshani et al., 2012).

The cultivation of microalgae, which can account for $30-40 \%$ of an aquaculture hatchery's operating expenses, is an economically expensive investment (Loo et al., 2013). In most cases, the general enriched seawater media (for example, Walne's medium and f/2 medium) are used in the laboratory cultivation of microalgae and a relatively small volume of microalgae productions can demand substantial resources. These economic challenges thus post a negative impact to the low investment as well as to the small- and medium-scale aquaculture hatcheries.

Efforts are put in to promote maximal growth of microalgae with minimal expenditures by substituting general enriched seawater media with alternative algal culture media as well as reducing the labour requirements (Sipaúba-Tavares et al., 2017). However, studies on the use and efficacy of alternative algal culture media in laboratory cultivation of microalgae are meagre (Valenzuela-Espinoza et al., 1999, 2002).

Isochrysis sp., measuring 4-6 $\mu \mathrm{m}$ in diameter (Thu et al., 2015), is a flagellated brown-golden marine microalga (Heimann and Huerlimann, 2015). It is conventionally used as live feed in shellfish hatcheries (Saoudi-Helis et al., 1994; Sánchez et al., 2000) in view of its good nutritional value, especially with respect to a high content of polyunsaturated fatty acids (PUFAs) (Wikfors and Patterson, 1994; Thu et al., 2015). In Guangxi Zhuang Autonomous Region, China, an algal culture medium with fewer nutrients (hereinafter referred to as the Chinacontributed culture medium (CCM)) has been commonly used in the cultivation of Isochrysis sp. in small- and medium-scale aquaculture hatcheries. The CCM can thus be adopted as a cost-effective alternative algal culture medium in Malaysia, however, the efficacy of CCM as an alternative has never been evaluated and compared to the 
general enriched seawater media in the laboratory cultivation of Isochrysis sp. Therefore, the present study aimed to evaluate the suitability of the introduced algal culture medium as an alternative to the general enriched seawater media through the examination of the growth performance of Isochrysis sp. cultivated in these algal culture media.

\section{Materials and Methods}

Marine microalga, Isochrysis sp., was obtained from the Live Feed Culture Laboratory of Borneo Marine Research Institute, Universiti Malaysia Sabah. Prior to the start of experiment, all glassware such as pipettes, conical flasks, bottles, etc., cotton plugs, distilled water and filtered 32 ppt saline water used in the laboratory were sterilised by autoclaving at $121^{\circ} \mathrm{C}$ for 15 minutes and allowed to cool to room temperature.

Three different algal culture media were tested, namely Walne's medium, CCM and CCM supplemented with vitamins (coded CCM + Vit). Walne's medium (a general enriched seawater medium which was used as a control) was prepared following Walne (1970), whilst the composition and preparations of introduced algal culture media of CCM and CCM + Vit are presented in Table 1.

Table 1. Composition of Walne's medium, Chinacontributed culture medium (CCM) and CCM supplemented with vitamins (CCM + Vit) for the cultivation of Isochrysis sp.

\begin{tabular}{|c|c|c|}
\hline Constituent & $\begin{array}{c}\text { Stock } \\
\text { solution } \\
\text { (per litre of } \\
\text { distilled } \\
\text { water) }\end{array}$ & $\begin{array}{l}\text { Working } \\
\text { solution } \\
\text { (per litre of } \\
\text { sterilised } \\
\text { seawater) }\end{array}$ \\
\hline
\end{tabular}

\section{Walne's medium:}

- Iron(III) chloride hexahydrate $\left(\mathrm{FeCl}_{3} .6 \mathrm{H}_{2} \mathrm{O}\right)$

$1.3 \mathrm{~g} \quad 1.0 \mathrm{~mL}$

- Manganese(II) chloride tetrahydrate $\left(\mathrm{MnCl}_{2} .4 \mathrm{H}_{2} \mathrm{O}\right)$

- Boric acid $\left(\mathrm{H}_{3} \mathrm{BO}_{3}\right)$

$\begin{array}{ll}33.6 \mathrm{~g} & 1.0 \mathrm{~mL} \\ 45.0 \mathrm{~g} & 1.0 \mathrm{~mL}\end{array}$
(Na2EDTA)

- Sodium dihydrogen phosphate dihydrate $\left(\mathrm{NaH}_{2} \mathrm{PO}_{4} .2 \mathrm{H}_{2} \mathrm{O}\right)$

$20.0 \mathrm{~g} \quad 1.0 \mathrm{~mL}$

- Sodium nitrate $\left(\mathrm{NaNO}_{3}\right)$

$100.0 \mathrm{~g}$

$1.0 \mathrm{~mL}$

- Zinc chloride $\left(\mathrm{ZnCl}_{2}\right)$

$21.0 \mathrm{~g} \quad 1.0 \mathrm{~mL}$

- Cobalt(II) chloride hexahydrate $20.0 \mathrm{~g}$ $1.0 \mathrm{~mL}$ $\left(\mathrm{CoCl}_{2} .6 \mathrm{H}_{2} \mathrm{O}\right)$

- Ammonium molybdate tetrahydrate $\left(\left(\mathrm{NH}_{4}\right)_{6} \mathrm{Mo}_{7} \mathrm{O}_{24} .4 \mathrm{H}_{2} \mathrm{O}\right)$

$9.0 \mathrm{~g} \quad 1.0 \mathrm{~mL}$

- Copper(II) sulphate pentahydrate $\left(\mathrm{CuSO}_{4} .5 \mathrm{H}_{2} \mathrm{O}\right)$

- Vitamin $B_{1}$ (Thiamine)

$100.0 \mathrm{mg} \quad 100.0 \mu \mathrm{L}$

- Vitamin $\mathrm{B}_{12}$ (Cyanocobalamin)

$100.0 \mathrm{mg} \quad 100.0 \mu \mathrm{L}$

\section{China-contributed culture medium (CCM):}

$40.0 \mathrm{~g}$

$1.5 \mathrm{~mL}$

- Potassium dihydrogenphosphate $\left(\mathrm{KH}_{2} \mathrm{PO}_{4}\right)$

- Iron(III) chloride $\left(\mathrm{FeCl}_{3}\right)$

$30.0 \mathrm{~g}$

$0.6 \mathrm{~mL}$

- Sodium silicate $\left(\mathrm{Na}_{2} \mathrm{SiO}_{3}\right)$

$10.0 \mathrm{~g}$

$0.6 \mathrm{~mL}$

- Urea $\left(\mathrm{CO}\left(\mathrm{NH}_{2}\right)_{2}\right)$

$30.0 \mathrm{~g}$

$0.8 \mathrm{~mL}$

$60.0 \mathrm{~g}$

$1.5 \mathrm{~mL}$

\section{Vitamins:}

- $\mathrm{B}_{1}$ (Thiamine) $\quad 100.0 \mathrm{mg} \quad 100.0 \mu \mathrm{L}$

- $\mathrm{B}_{12}$ (Cyanocobalamin) $\quad 100.0 \mathrm{mg} \quad 100.0 \mu \mathrm{L}$

Three replications of $100 \mathrm{~mL}$ conical flasks were prepared for the cultivation of Isochrysis sp. in the experimental algal culture media with the proportion of 1:1 (Isochrysis sp.: fresh algal culture media). The inoculated cultures, with initial cell densities between $1.95 \times 10^{6} \pm 4.70 \times 10^{5}$ cells $\mathrm{mL}^{-1}$ and $2.16 \times 10^{6} \pm 3.40 \times 10^{5}$ cells $\mathrm{mL}^{-1}$, were illuminated continuously with a fluorescent lamp (23 W E27 cap cool daylight bulb, Philips Lighting Commercial Malaysia Sdn. Bhd., Selangor Darul Ehsan, Malaysia) at $25 \pm 1^{\circ} \mathrm{C}$. To keep out dust and reduce evaporation, all nine experimental flasks were stoppered by means of cotton plugs and covered with aluminium foil (Becker, 1994; Renaud et al., 2002). Throughout the experimental period of seven days (Valenzuela-Espinoza et al., 2002), the cultures were shaken gently twice daily in the morning and afternoon to accelerate the growth of Isochrysis sp. (Ilavarasi et al., 2011; Idenyi et al., 2016; Eshak and Wan-Omar, 2017). 
During the course of the experimental period, 10 $\mu \mathrm{L}$ aliquot from each culture was sampled into a microcentrifuge tube to which $10 \mu \mathrm{L}$ of Lugol's iodine was added to fix the Isochrysis sp. Cell densities of Isochrysis sp. were quantified in duplicate every $24 \mathrm{~h}$ with a haemocytometer (Double cell standard improved Neubauer, OPTIK-Labor, Görlitz, Germany) placed under a light microscope (Zeiss Axiostar, Carl Zeiss Inc., Göttingen, Germany).

At the end of the experiment, instantaneous growth rate $(r)$, divisions per day $(k)$ and doubling time $\left(T_{2}\right)$ of Isochrysis sp. cultivated in the experimental algal culture media were calculated according to the formulae as follows (Michelle-Wood et al., 2005):

$$
r=\frac{\ln \mathrm{N}_{\mathrm{t}}-\ln \mathrm{N}_{0}}{\Delta \mathrm{t}}
$$

where $r$ is the instantaneous growth rate (cell day ${ }^{-1}$ ) of Isochrysis sp., $\mathrm{N}_{\mathrm{t}}$ is the population size of Isochrysis sp. at the end of the time interval, $\mathrm{N}_{0}$ is the population size of Isochrysis sp. at the beginning of the time interval and $\Delta \mathrm{t}$ is the length of the time interval $\left(\mathrm{t}_{\mathrm{t}}-\mathrm{t}_{0}\right)$.

$$
k=\frac{\log _{2}\left(\mathrm{~N}_{\mathrm{t}} / \mathrm{N}_{0}\right)}{\Delta \mathrm{t}}
$$

where $k$ is the divisions per day of Isochrysis sp., $\mathrm{N}_{\mathrm{t}}$ is the population size of Isochrysis sp. at the end of the time interval, $\mathrm{N}_{0}$ is the population size of Isochrysis sp. at the beginning of the time interval and $\Delta t$ is the length of the time interval $\left(\mathrm{t}_{\mathrm{t}}-\mathrm{t}_{0}\right)$.

$$
T_{2}=\frac{0.6931}{r}
$$

where $T_{2}$ is the doubling time of Isochrysis sp. and $r$ is the instantaneous growth rate (cell day ${ }^{-1}$ ) of Isochrysis sp.

Data collected were analysed by one-way analysis of variance (ANOVA). Tukey's multiple comparison test was conducted to examine the significance of difference $(\mathrm{P}<0.05)$ in means among the treatments when the results of one-way ANOVA were significant. Prior to conducting the one-way ANOVA, Shapiro-Wilk test and Levene's test were performed to assess the assumptions of normality and homogeneity of variance, respectively. These statistical analyses were performed using IBM SPSS Statistics ver. 20 (IBM Corp., New York, USA).

\section{Results}

The growth of Isochrysis sp. expressed in cell density in different experimental algal culture media is presented in Figure 1. A maximum cell density of $1.22 \times 10^{7} \pm 4.59 \times 10^{6}$ cells $\mathrm{mL}^{-1}$ was observed in Isochrysis sp. cultivated in Walne's medium on day six of the experimental period. By contrast, maximum cell densities of $9.16 \times 10^{6} \pm 5.40 \times 10^{5}$ cells $\mathrm{mL}^{-1}$ and $7.36 \times 10^{6} \pm 4.31 \times 10^{5}$ cells $\mathrm{mL}^{-1}$ were observed in Isochrysis sp. cultivated in CCM and CCM + Vit, respectively on day seven of the experimental period.

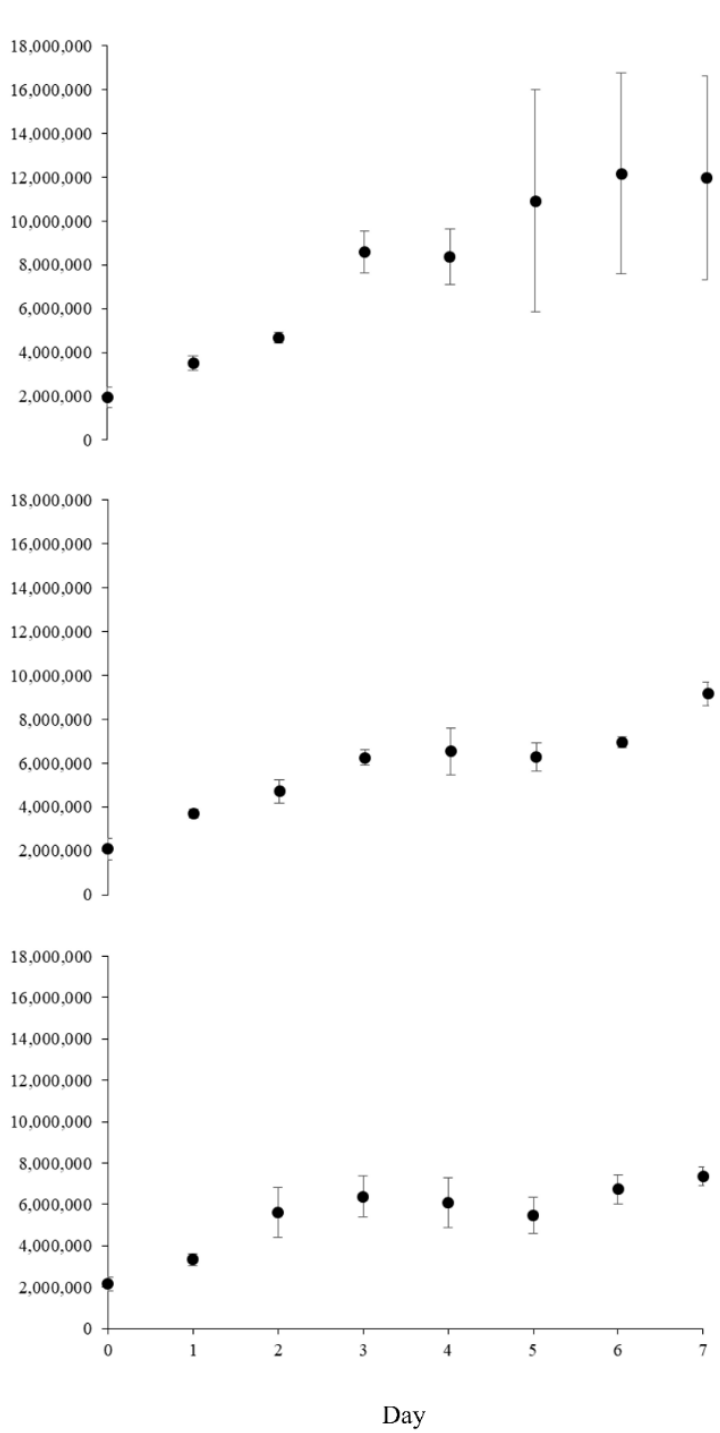

(a)

(b)

Figure 1. Cell densities (mean \pm standard deviation) of Isochrysis sp. cultivated in (a) Walne's medium, (b) Chinacontributed culture medium (CCM) and (c) CCM supplemented with vitamins (CCM + Vit).

The results of one-way ANOVA showed that there was no significant difference $(P>0.05)$ among the growth performance of Isochrysis sp. cultivated in different experimental algal culture media. However, a tendency towards higher growth performance was observed in Isochrysis sp. cultivated in Walne's medium (see Table 2). Isochrysis sp. grew at a rate $(k)$ of 0.37 division day ${ }^{-1}$ had a doubling time $\left(T_{2}\right)$ of 2.67 days and an instantaneous growth rate $(r)$ of 0.26 cell day $^{-1}$. In CCM, Isochrysis sp. exhibited an instantaneous growth rate $(r)$ of 0.21 cell day $^{-1}$, which corresponded to a rate $(k)$ of 0.30 division day $^{-1}$ and a doubling time ( $\left.T_{2}\right)$ of 3.29 days. Meanwhile, an instantaneous growth rate $(r)$ of 0.18 cell day ${ }^{-1}$, corresponding to a rate $(k)$ of 0.25 division day ${ }^{-1}$ and a doubling time $\left(T_{2}\right)$ of 3.95 days, was observed in Isochrysis sp. cultivated in CCM + Vit. 
Table 2. Instantaneous growth rate $(r)$, divisions per day $(k)$ and doubling time $\left(T_{2}\right)$ of Isochrysis sp. cultivated in the Walne's medium, China-contributed culture medium (CCM) and CCM supplemented with vitamins (CCM + Vit), respectively.

\begin{tabular}{|c|c|c|c|c|c|c|c|c|c|c|c|}
\hline & & \multicolumn{10}{|c|}{ Time interval (Day) } \\
\hline & & $0-1$ & $1-2$ & $2-3$ & $3-4$ & $4-5$ & $5-6$ & $6-7$ & $0-3$ & $5-7$ & $0-7$ \\
\hline \multirow{3}{*}{ 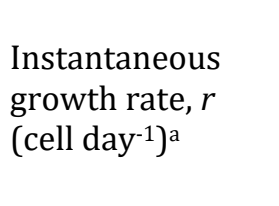 } & Walne's & 0.58 & 0.29 & 0.61 & -0.03 & 0.27 & 0.11 & -0.02 & 0.49 & 0.05 & 0.26 \\
\hline & $\mathrm{CCM}$ & 0.57 & 0.24 & 0.28 & 0.04 & -0.04 & 0.10 & 0.28 & 0.36 & 0.19 & 0.21 \\
\hline & $\mathrm{CCM}+\mathrm{Vit}$ & 0.44 & 0.52 & 0.13 & -0.05 & -0.10 & 0.21 & 0.09 & 0.36 & 0.15 & 0.18 \\
\hline \multirow{3}{*}{$\begin{array}{l}\text { Divisions per } \\
\text { day, } k\end{array}$} & Walne's & 0.84 & 0.42 & 0.88 & -0.04 & 0.38 & 0.16 & -0.02 & 0.71 & 0.07 & 0.37 \\
\hline & $\mathrm{CCM}$ & 0.82 & 0.34 & 0.41 & 0.06 & -0.06 & 0.15 & 0.40 & 0.53 & 0.27 & 0.30 \\
\hline & $\mathrm{CCM}+\mathrm{Vit}$ & 0.63 & 0.75 & 0.18 & -0.07 & -0.15 & 0.30 & 0.13 & 0.52 & 0.21 & 0.25 \\
\hline \multirow{3}{*}{ Doubling time, $T_{2}$} & Walne's & 1.19 & 2.38 & 1.14 & -26.72 & 2.61 & 6.43 & -45.64 & 1.40 & 14.96 & 2.67 \\
\hline & CCM & 1.21 & 2.90 & 2.44 & 15.82 & -16.63 & 6.73 & 2.51 & 1.90 & 3.65 & 3.29 \\
\hline & $\mathrm{CCM}+\mathrm{Vit}$ & 1.58 & 1.34 & 5.46 & -14.71 & -6.67 & 3.35 & 7.92 & 1.92 & 4.71 & 3.95 \\
\hline
\end{tabular}

a Assuming exponential growth and zero mortality

\section{Discussion}

The introduced algal culture medium of CCM demonstrated promising results for the cultivation of Isochrysis sp. A basic algal culture medium is composed of macronutrients, trace elements and vitamins (Watanabe, 2005; de Carvalho et al., 2019). The composition of algal culture media is an important factor in the growth performance of microalgae (Lin et al., 2007; Li et al., 2010; de Carvalho et al., 2019). The principle macronutrients that microalgae require are nitrate, phosphate and silicate (form of nitrogen, phosphorus and silicon, respectively) (Takeda, 1998; Perumal et al., 2015). In the present study, CCM could be a good source of nitrogen, phosphorus and silicon for cultivating Isochrysis sp. Nitrogen, which is vital in the formation of chlorophyll for photosynthesis and synthesis of proteins (Verma et al., 2015), was sourced from sodium nitrate $\left(\mathrm{NaNO}_{3}\right)$ and urea $\left(\mathrm{CO}\left(\mathrm{NH}_{2}\right)_{2}\right)$. Potassium dihydrogenphosphate $\left(\mathrm{KH}_{2} \mathrm{PO}_{4}\right)$ was the source of phosphorus, a key factor that regulates the growth and metabolism of cells (Liang et al., 2013). Sodium silicate $\left(\mathrm{Na}_{2} \mathrm{SiO}_{3}\right)$, source of silicon/silicate in the present study, is responsible for alkaline buffering in algal culture media (Idenyi et al., 2016). Furthermore, trace element iron is essential in metabolic functions of microalgae, for example, photosynthetic electron transport as well as metabolism of oxygen (Sunda et al., 2005; Yalcin-Duygu et al., 2018), and iron(III) chloride $\left(\mathrm{FeCl}_{3}\right)$ in CCM served as the iron source for the present study. Vitamins, which are essential to normal metabolic functioning of microalgae (Del-Mondo et al., 2020), are commonly present in the composition of most algal culture media (Andersen et al., 2005). In the present study, among the three experimental algal culture media, only Walne's medium and CCM + Vit contained vitamins. The growth performance of Isochrysis sp. cultivated in Walne's medium was not significantly differed $(\mathrm{P}>0.05)$ from those cultivated in CCM and CCM + Vit. In addition, by comparing between the two introduced algal culture media, a tendency towards higher growth performance was observed in Isochrysis sp. cultivated in CCM. These results indicated that a change in the composition of algal culture media did not affect the growth performance of Isochrysis sp. (Valenzuela-Espinoza et al., 2002). Since no significant changes was observed in the growth performance of Isochrysis sp. (with or without vitamins in the present study), we believed that CCM was able to provide necessary nutrients for the growth of Isochrysis sp. and may be recommended as a cost-effective alternative algal culture medium.

Doubling time $\left(T_{2}\right)$ refers to the time required for microalgae to divide (Michelle-Wood et al., 2005). A shorter doubling time corresponds to a higher instantaneous growth rate $(r)$ (Liu et al., 2011). In the present study, Isochrysis sp. cultivated in Walne's medium, CCM and CCM + Vit had a doubling time of 2.67, $3.29,3.95$ days, corresponding to an instantaneous growth rate of $0.26,0.21,0.18$ cell day $^{-1}$, respectively. With respect to the growth performance of Isochrysis sp. cultivated in Walne's medium $\left(T_{2}=2.67 ; r=0.26\right.$ cell day $\left.{ }^{1}\right)$, the microalga had a lower growth than Isochrysis maritima $\left(r=0.52-0.82\right.$ cell day $^{-1}$ ) (Eshak and Wan-Omar, 2017) and Isochrysis galbana $\left(r=0.62\right.$ cell day $\left.{ }^{-1}\right)$ cultivated in Walne's medium (Zhu et al., 1997). On the other hand, Isochrysis sp. cultivated in CCM $\left(T_{2}=3.29 ; r=\right.$ 


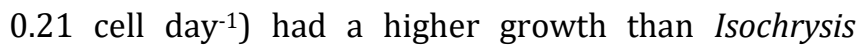
galbana cultivated in Walne's medium $\left(T_{2}=3.85 ; r=0.18\right.$ cell day-1) (Sukarni et al., 2018). These indicated that growth performance of Isochrysis may vary among species or strains (Liu et al., 2013) and each microalga species has specific requirement for optimal growth (Alvarez-Cobelas et al., 1998). Apparently, the differences in growth performance of microalgae can be attributed to the composition of algal culture media and a combination of different environmental factors, such as temperature, light intensity, photoperiod, $\mathrm{pH}$, concentration of carbon dioxide and rate of aeration (Kumar and Das, 2012; Krishnan et al., 2015; Idenyi et al., 2016). Although the aforementioned comparisons provide a general overview, cultivation of Isochrysis sp. may be improved by environmental factors and culture modes optimising, with regard to introduced algal culture medium of CCM.

\section{Conclusion}

In conclusion, CCM is a promising alternative algal culture medium next to Walne's medium to cultivate Isochrysis sp. In consideration of its potential and reduced preparation labour (i.e., less tedious and time-consuming in algal culture media preparation compared with the procedure for general enriched seawater media preparation), CCM may be recommended as an alternative to the general enriched seawater media in the cultivation of Isochrysis sp. in laboratories with basic facility as well as small- and medium-scale aquaculture hatcheries. However, further study on optimisation of environmental factors and culture modes for the cultivation of Isochrysis sp. in CCM is necessary to present optimal cultivation conditions for Isochrysis sp. Additionally, the biochemical composition of Isochrysis sp. cultivated in CCM and other algal culture media will greatly determine the value of Isochrysis sp. in economic considerations as well as production efficiency in aquaculture.

\section{Acknowledgements}

The first author is particularly grateful to Science and Technology Department of Guangxi Zhuang Autonomous Region of People's Republic of China for offering him fellowship under the ASEAN Talented Young Scientists Guangxi Program (ATYSP) 2019. The authors would like to acknowledge Mrs Henrieta Lidya Lawrence, Mr Yusdi Ismail and Ms Asilah Al-Has for their technical assistance.

\section{References}

Adewumi, A.A. \& Olaleye, V.F. (2011). Catfish culture in Nigeria: Progress, prospects and problems. African Journal of Agricultural Research 6(6), 1281-1285.

Andersen, R.A., Berges, J.A., Harrison, P.J. \& Watanabe, M.M. (2005). Appendix A - Recipes for freshwater and seawater media. In: Algal Culturing Techniques (R.A. Andersen, ed.), pp 429-538. Elsevier Academic Press, Burlington, USA.
Alvarez-Cobelas, M., Reynolds, C.S., Sánchez-Castillo, P. \& Kristiansen, J. (1998). Phytoplankton and Trophic Gradients. Kluwer Academic Publishers, 372 pp. Kluwer Academic Publishers, Belgium.

Becker, E.W. (1994). Microalgae: Biotechnology and Microbiology. Cambridge University Press, 293 pp. Cambridge University Press, Cambridge, UK.

Creswell, L. (2010). Phytoplankton culture for aquaculture. Southern Regional Aquaculture Center Publication No. 5004. Mississippi State University, Mississippi, USA.

de Carvalho, J.C., Sydney, E.B., Tessari, L.F.A. \& Soccol, C.R. (2019) Chapter 2 - Culture media for mass production of microalgae. In: Biomass, Biofuels and Biochemicals: Biofuels from Algae ( $2^{\text {nd }}$ edn.) (A. Pandey, J.S. Chang, C.R. Soccol, D.J. Lee \& Y. Chisti, eds.), pp 33-50. Elsevier B.V., Amsterdam, Netherlands.

Del-Mondo, A., Smerilli, A., Sané, E., Sansone, C. \& Brunet, C. (2020). Challenging microalgal vitamins for human health. Microbial Cell Factories 19, 201.

Eshak, M.B. \& Wan-Omar, W.M. (2017). Isochrysis maritima Billard and Gayral isolated from Penang National Park coastal waters as a potential microalgae for aquaculture. Tropical Life Sciences Research 28(2), 163-176.

Food and Agriculture Organisation of the United Nations. (1988). Definition of aquaculture. In: Seventh Session of the IPFC Working Party of Expects on Aquaculture IPFC/WPA/WPZ, pp 1-3. RAPA/FAO, Bangkok, Thailand.

Heimann, K. \& Huerlimann, R. (2015). Chapter 3 - Microalgal classification: Major classes and genera of commercial microalgal species. In: Handbook of Marine Microalgae: Biotechnology Advances (S.K. Kim, ed.), pp 25-41. Elsevier Academic Press, London, UK.

Idenyi, J.N., Ebenyi, L.N., Ogah, O., Nwali, B.U. \& Ogbanshi, M.E. (2016). Effect of different growth media on the cell densities of freshwater microalgae isolates. Journal of Pharmacy and Biological Sciences 11(3), 24-28.

Ilavarasi, A., Mubarakali, D., Praveenkumar, R., Baldev, E. \& Thajuddin, N. (2011). Optimization of various growth media to freshwater microalgae for biomass production. Biotechnology 10(6), 540-545.

Khatoon, H., Yusoff, F.M., Banerjee, S., Shariff, M. \& Mohamed, S. (2007). Use of periphytic cyanobacterium and mixed diatoms coated substrate for improving water quality, survival and growth of Penaeus monodon Fabricius postlarvae. Aquaculture 271, 196-205.

Krishnan, V., Uemura, Y., Thanh, N.T., Abdul-Khalid, N., Osman, N. \& Mansor, N. (2015). Three types of marine microalgae and Nannochloropsis oculata cultivation for potential source of biomass production. Journal of Physics: Conference Series 622, 012034.

Kumar, K. \& Das, D. (2012). Growth characteristics of Chlorella sorokiniana in airlift and bubble column photo-bioreactors. Bioresource Technology 116, 307-313.

Li, X., Hu, H.Y., Gan, K. \& Sun, Y.X. (2010). Effects of different nitrogen and phosphorus concentrations on the growth, nutrient uptake, and lipid accumulation of a freshwater microalga Scenedesmus sp. Bioresource Technology 101(14), 5494-5500.

Liang, K.H., Zhang, Q.H., Gu, M. \& Cong, W. (2013). Effect of phosphorus on lipid accumulation in freshwater microalga Chlorella sp. Journal of Applied Phycology 25, 311-318.

Lin, Y.H., Chang, F.L., Tsao, C.Y. \& Leu, J.Y. (2007). Influence of growth phase and nutrient source on fatty acid composition of Isochrysis galbana CCMP 1324 in a batch photoreactor. Biochemical Engineering Journal 37, 166-176. 
Liu, J., Huang, J.C. \& Chen, F. (2011). Microalgae as feedstocks for biodiesel production. In: Biodiesel - Feedstocks and Processing Technologies (M. Stoytcheva, ed.), pp 133-160. InTech, Shanghai, China.

Liu, J., Sommerfeld, M. \& Hu, Q. (2013). Screening and characterization of Isochrysis strains and optimization of culture conditions for docosahexaenoic acid production. Applied Microbiology and Biotechnology 97, 4785-4798.

Loo, P.L., Chong, V.C. \& Vikineswary, S. (2013). Rhodovulum sulfidophilum, a phototrophic bacterium, grown in palm oil mill effluent improves the larval survival of marble goby Oxyeleotris marmorata (Bleeker). Aquaculture Research 44, 495-507.

Meireles, L.A., Guedes, A.C. \& Malcata, F.X. (2003). Lipid class composition of the microalga Pavlova lutheri: eicosapentaenoic and docosahexaenoic acids. Journal of Agricultural and Food Chemistry 51(8), 2237-2241.

Michelle-Wood, A., Everroad, R.C. \& Wingard, L.M. (2005). Measuring growth rates in microalgal cultures. In: Algal Culturing Techniques (R.A. Andersen, ed.), pp 269-286. Elsevier Academic Press, Burlington, USA.

Parker, R. (2011). Aquaculture Science (3 ${ }^{\text {rd }}$ edn.). Delmar Cengage Learning, pp 2-27. Delmar Cengage Learning, USA.

Perumal, P., Balaji-Prasath, B., Santhanam, P., Ananth, S., ShenbagaDevi, A., Dinesh-Kumar, S. \& Jeyanthi, S. (2015). Isolation and culture of microalgae. In: Advances in Marine and Brackishwater Aquaculture (P. Santhanam, A.R. Thirunavukkarasu \& P. Perumal, eds.), pp 1-15. Springer, New Delhi, India.

Priyadarshani, I., Sahu, D. \& Rath, B. (2012). Algae in aquaculture. International Journal of Health Sciences and Research 2(1), 108114.

Renaud, S.M., Thinh, L.V., Lambrinidis, G. \& Parry, D.L. (2002). Effect of temperature on growth, chemical composition and fatty acid composition of tropical Australian microalgae grown in batch cultures. Aquaculture 211, 195-214.

Sánchez, S., Martínez, M.E. \& Espinola, F. (2000). Biomass production and biochemical variability of the marine microalga Isochrysis galbana in relation to culture medium. Biochemical Engineering Journal 6(1), 13-18.

Saoudi-Helis, L., Dubacq, J.P., Marty, Y., Samain, J.F. \& Gudin, C. (1994). Influence of growth rate on pigment and lipid composition of the microalga Isochrysis aff. galbana clone T.iso. Journal of Applied Phycology 6, 315-322.

Sipaúba-Tavares, L.H., Segali, A.M.D.L., Berchielli-Morais, F.A. \& Scardoeli-Truzzi, B. (2017). Development of low-cost culture media for Ankistrodesmus gracilis based on inorganic fertilizer and macrophyte. Acta Limnologica Brasiliensia 29, e5.

Sukarni, S., Sumarli, S., Nauri, I.M., Purnami, P., al Mufid, A. \& Yanuhar, U. (2018). Exploring the prospect of marine microalgae Isochrysis galbana as sustainable solid biofuel feedstock. Journal of Applied Research and Technology 16, 53-66.

Sunda, W.G., Price, N.M. \& Morel, F.M.M. (2005). Trace metal ion buffers and their use in culture studies. In: Algal Culturing Techniques (R.A. Andersen, ed.), pp 35-63. Elsevier Academic Press, Burlington, USA.

Takeda, S. (1998). Influence of iron availability on nutrient consumption ratio of diatoms in oceanic waters. Nature 33, 774-777.

Thu, N.T.H., Anh, H.T.L., Hoang, M.H., Kim, D.D. \& Hong, D.D. (2015). Study on biological characteristics of a newly isolated Vietnamese strain of microalga Isochrysis galbana Parke for utilizing as live aquaculture feed. Russian Journal of Marine Biology 41(3), 203-211.
Valenzuela-Espinoza, E., Millan-Nuñez, R. \& Núñez-Cebrero, F. (1999). Biomass production and nutrient uptake by Isochrysis aff galbana (Clone T-ISO) cultured with a low cost alternative to the $\mathrm{f} / 2$ medium. Aquacultural Engineering 20, 135-147.

Valenzuela-Espinoza, E., Millan-Nuñez, R. \& Núñez-Cebrero, F. (2002). Protein, carbohydrate, lipid and chlorophyll $a$ content in Isochrysis aff. galbana (clone T-Iso) cultured with a low cost alternative to the f/2 medium. Aquacultural Engineering 25, 207-216.

Verma, R., Fulekar, M.H. \& Pathak, B. (2015). Effect of different culture media formulations on growth and biodiesel production potential of Chlorella pyrenoidosa. Journal of Algal Biomass Utilization 6(3), 7-15.

Walne, P.R. (1970). Studies on the food value of nineteen genera of algae to juvenile bivalves of the genera Ostrea, Crassostrea, Mercenaria, and Mytilis. Fishery Investigations 26, 1-62.

Watanabe, M.M. (2005). Freshwater culture media. In: Algal Culturing Techniques (R.A. Andersen, ed.), pp 13-20. Elsevier Academic Press, Burlington, USA.

Wikfors, G.H. \& Patterson, G.W. (1994). Differences in strains of Isochrysis of importance to mariculture. Aquaculture 123, 127-135.

Yalcin-Duygu, D., Açikgöz-Erkaya, I. \& Özer, T. (2018). Investigating the effect of different growth media on biomass production of Pseudopediastrum boryanum (Turpin) E. Hegewald isolates. Journal of Limnology and Freshwater Fisheries Research 4(1), 6-12.

Zhu, C.J., Lee, Y.K. \& Chao, T.M. (1997). Effects of temperature and growth phase on lipid and biochemical composition of Isochrysis galbana TK1. Journal of Applied Phycology 9, 451-457. 